\title{
COMPOSITION AND SEASONAL ABUNDANCE OF HOVER FLIES (DIPTERA: SYRPHIDAE) AT A MIDELEVATION SITE IN CENTRAL UTAH
}

\author{
Tyson J. Terry 1,2 and C. Riley Nelson ${ }^{1}$
}

\begin{abstract}
Dipteran pollinators are important in the successful reproduction of many plants, yet are less studied than other groups. We know that these insects affect the biodiversity of natural landscapes, yet much remains unknown about the extent of their influence in pollination systems and flight seasons. In this study, we collected hover flies (Diptera: Syrphidae) with 3 Malaise traps at a midelevation site in central Utah throughout the flies' flight season of 2015. We collected 27 genera and 48 species in our traps. We determined seasonal flight times by collecting at weekly intervals throughout the frost-free year. Abundance of all hover flies peaked twice, in June and September, showing a bimodal distribution. We noted a drop in overall abundance during the hottest months of July and August. Species diversity and richness also peaked in June and September. We calculated species richness estimators, which suggest that more than 60 species make up the total assemblage at the study site. Local museum records show 28 species caught in similar locations near the sample site before the year 2000 that were not collected during our study.
\end{abstract}

REsumen.-Los polinizadores dípteros son cruciales para la reproducción exitosa de muchas plantas, sin embargo, son menos estudiados que otros grupos. Sabemos que tienen impacto en la biodiversidad de los entornos naturales, aún así queda mucho por conocer sobre la magnitud de su influencia en los sistemas de polinización y en las temporadas migratorias. En este estudio se colectaron moscas voladoras (Diptera: Syrphidae) a lo largo de la temporada migratoria del año 2015, mediante el empleo de tres trampas para insectos voladores, en una zona de mediana elevación en el centro de Utah. Mediante esta técnica, colectamos 27 géneros y 48 especies. Determinamos las épocas de temporadas migratorias mediante colectas en intervalos semanales, durante el año libre de heladas. La abundancia de las moscas voladoras alcanzó su pico máximo dos veces (en junio y en septiembre) mostrando una distribución bimodal, a la vez que notamos una caída en su abundancia general durante los meses más calurosos (en julio y en agosto). La diversidad y la riqueza de las especies también alcanzaron su punto máximo en junio y en septiembre. Calculamos, también, los estimadores de riqueza de especies, que sugirieron que más de 60 especies forman el grupo total en el área de estudio. Los registros de los museos locales muestran 28 especies en sitios similares (cercanos al sitio de prueba) capturadas antes del año 2000 y que no fueron colectadas durante nuestro estudio.

Hover flies are a diverse group of pollinators in the dipteran family Syrphidae. In the Nearctic region alone, there are 812 species (Miranda et al. 2013). Often referred to as flower flies, they feed on pollen and nectar as adults (Holloway 1976, Kevan and Baker 1983). In some species, females require pollen during stages of ovarian development, although both males and females (before and after oogenesis) consume large amounts of nectar and pollen (Holloway 1976, Haslett 1989, Inouye et al. 2015). Although syrphids have been recognized in several studies to be significant pollinators across diverse systems, much of their basic biology has yet to be discovered (Larson et al. 2001, Ssymank et al. 2008, Stanley et al. 2013). Many studies identify the importance of a few taxa to cultivated crops (such as sweet peppers), but information on the contributions of syrphids in their native environments is sparse (Ssymank et al. 2008). The vital role of hover flies in maintaining ecosystem health goes beyond pollination services, as some taxa also prey on aphids and other soft-bodied plant pests (Thompson and Vockeroth 1989). Many hover flies are likely to be bioindicators of community health in their ecosystems because they integrate their life history across diverse feeding strategies, but more intensive studies are needed to fully understand this role (Kevan 1999). Moreover, the diverse habits of syrphid larvae (phytophagy, mycophagy, saprophagy, and zoophagy) suggest that lowered syrphid diversity could reflect environmental stress and loss of landscape diversity (Thompson and Vockeroth 1989, Sommaggio 1999).

\footnotetext{
${ }^{1}$ Department of Biology and Monte L. Bean Life Science Museum, Brigham Young University, Provo, UT 84602.

${ }^{2}$ E-mail: tysonjterry@gmail.com
} 


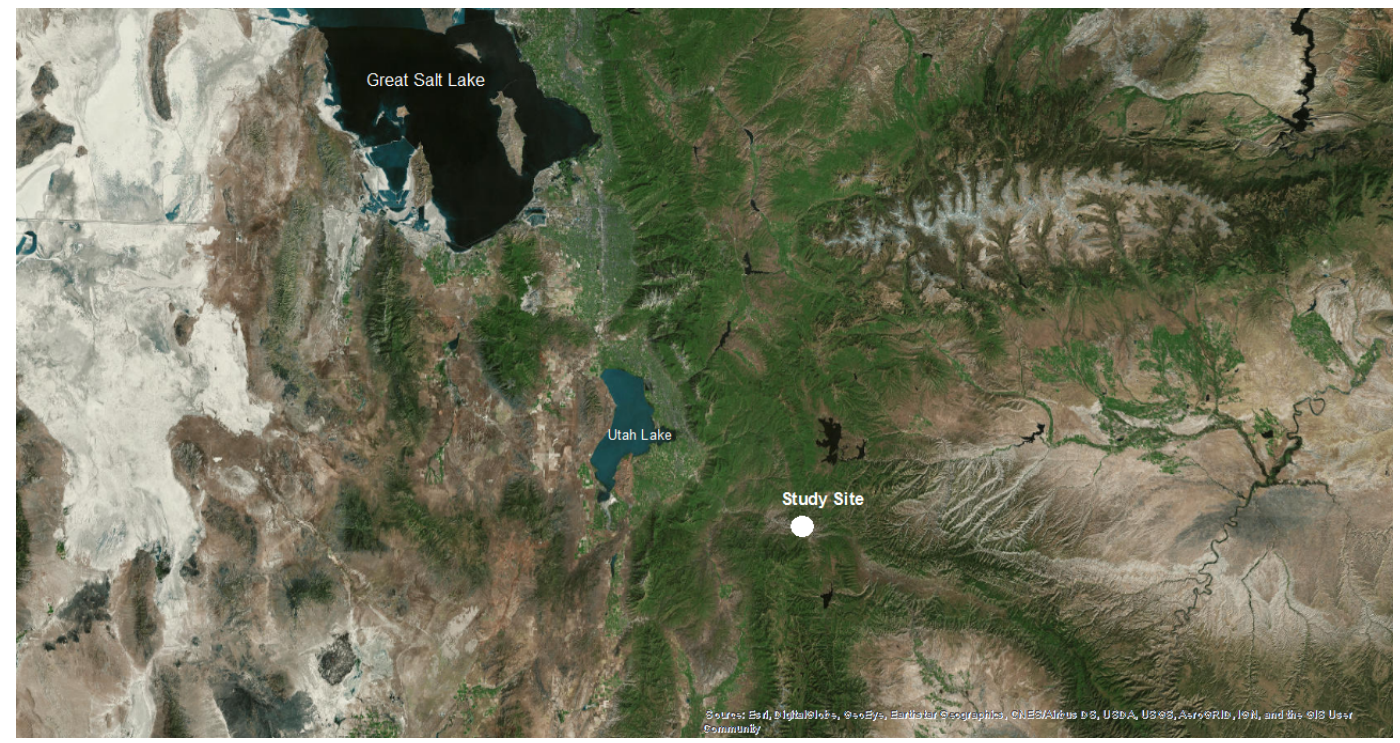

Fig. 1. Location of study site in central Utah.

Pollinating flies have a significant effect on the biodiversity of plants in natural landscapes. Gaps in knowledge of pollinating flies and their reactions to climate change prevent more effective conservation plans (Ssymank et al. 2008). Floral constancy is thought to be very high among the Syrphidae due to preference in flower height, color, and type (Ssymack 2003), which likely created close evolutionary relationships of syrphid species with specific angiosperms (Inouye et al. 2015). Dipteran pollinators are thought to be especially important in Arctic and montane-alpine environments because of their active foraging in wetter and colder climates (Kearns 1990), matched with the limited availability of flowering species (Kevan 1972). The availability of only a couple of flowering plant species at a time forces pollinators to visit conspecific plants, thereby increasing the likelihood of successful pollination (Kevan 1972).

Analysis in some parts of Europe suggest hover fly decline and shifts in distribution (Biesmeijer et al. 2006). In the Rocky Mountains, very few studies have been done specifically on this group of Diptera beyond basic taxonomic works, and few of these have been conducted in recent years. Much information on hover fly distribution and abundance remains unknown (Sedman 1952). With little data on abundance and flight season, it is nearly impossible to track changes and responses of syrphids to new ecological stresses. Size and diversity of hover fly populations can be difficult to quantify because of the short flight season of some species (Speight 1986, Speight and Castella 1993) and lack of focused attention from the scientific community. The ease of use of passive Malaise traps to sample the flies can alleviate many of these concerns.

We conducted our study to more fully understand the composition of hover fly species and their changes in abundance throughout the flight year. Though recent review papers such as Inouye et al. (2015) give us a great background on the ecology of syrphids, this paper attempts to fill some of the voids in knowledge of this important group of insects.

\section{Methods \\ Study Site}

We sampled syrphids during the generally frost-free months of April through November in 2015 at a midelevation site $(1820 \mathrm{~m} \pm 45 \mathrm{~m})$ in central Utah $\left(39.95864^{\circ} \mathrm{N}, 111.26742^{\circ} \mathrm{W}\right.$; $\pm 400 \mathrm{~m}$ ) (Fig. 1). Our study site was in a mountainous region where the Colorado Plateau and Central Basin ecoregions overlap (EPA 2006). The canyon is flanked by steep slopes. On our site the riparian vegetation is dominated by willows and cottonwoods, with a 
diversity of smaller flowering plants. Beyond the riparian corridor, dominant vegetation includes rubber rabbitbrush (Ericameria nauseosa), big sagebrush (Artemisia tridentata), Gambel oak (Quercus gambelii), bigtooth maple (Acer grandidentatum), Canada goldenrod (Solidago canadensis), and thistle (Carduus sp.). Most precipitation (65\%) occurs from October through April in the form of snow, and $35 \%$ occurs as rain from May through September (EPA 2006). Water flow exhibits a normal snowmelt-dominated flow pattern and peaks in May and June. The driest months of the year are July and August (EPA 2006). Water in western canyons is extremely important for general biodiversity, as wetter canyons support a broader spectrum of plants (Schoeneberger 1992). The largest water source in the canyon, Soldier Creek, fulfills that need, but is on the Utah 303(d) list of impaired waterbodies for high total phosphorus and heavy sedimentation/siltation (Division of Water Quality 2014) for use by aquatic life. Unstable vertical banks and high soil erosion contribute to the sedimentation of the waterway (EPA 2006).

We selected our sampling location in Spanish Fork Canyon 12 miles east of Thistle near Highway 89 (Fig. 1). The segments of waterways on the sample site are on private land and are inaccessible to the public, and thus remain less disturbed at the riparian border and in the immediate surroundings. The 3 trap sites have an elevation difference of $<45 \mathrm{~m}$ and are within $300 \mathrm{~m}$ of each other. We deployed one Malaise trap at each site throughout the sampling period. We chose sites to represent diversity in terrain and vegetation over a localized area. We chose locations having rather low apparent human/agricultural impact, along with extensive vegetation and good apparent riparian health. We placed the traps over small creeks because vegetation was denser and more diverse along these water sources. This had the secondary advantage of funneling flying insects into the traps. Trap 1 was placed over a first-order spring-fed stream in a narrow side canyon, $50 \mathrm{~m}$ below the source. This location is well shaded for a good portion of the day. Trap 2 was placed over a second-order stream (Soldier Creek) in an open meadow within the larger canyon (Spanish Fork Canyon). This location was in full sunlight throughout the day. We placed trap 3 near the base of a small spring-fed waterfall. The rock face where the waterfall occurs is covered in moss and sediment buildup with significant hygropetric habitats. We chose these 3 locations to represent diverse terrain in close proximity, thereby maximizing potential plant and syrphid diversity in the area.

\section{Collection and Analysis}

We visited the traps on a weekly basis to collect samples and to maintain the traps in good working condition. We collected a total of 90 week-long samples, which we then combined over the 3 traps by week to provide 30 one-week samples spanning the flight period at the study site. Townes-style Malaise traps collected insects in $500-\mathrm{mL}$ bottles of $70 \%$ ethanol. We sorted the samples to family in the laboratory at Brigham Young University (BYU) in Provo, Utah, using an Olympus SZ61 stereo microscope. Families were placed in individual 10 - or $50-\mathrm{mL}$ plastic capped vials, with vial size dependent on the number and bulk of specimens. The senior author sorted all specimens belonging to Syrphidae to genus using the key by Miranda et al. (2013). We used specimens from the Monte L. Bean Life Science Museum (MLBM) at Brigham Young University (BYU) identified by prominent authorities to confirm and clarify our generic identifications. All specimens were dried before being identified to the genus and species levels. To dry the specimens, we submerged them in ethyl acetate for $15 \mathrm{~min}$ and then pinned or point mounted them. We placed the drying specimens in an undisturbed cabinet for $48 \mathrm{~h}$ before further identification. The specimens were then identified to species using several dichotomous keys that were chosen from references in Miranda et al. (2013). We also used the species lists from Miranda et al. (2013) to verify that names were those most currently used.

We searched the extensive insect collection at the MLBM to find historic records of hover fly specimens found within $50 \mathrm{~km}$ of the sample site and at a similar elevation (within $200 \mathrm{~m}$ ). These specimens were reexamined to confirm that names were those most currently used (Miranda et al. 2013). Names were checked against the species lists, generic key, and listed-species keys from the publication used to identify the collected samples from the study site (Miranda et al 2013). 


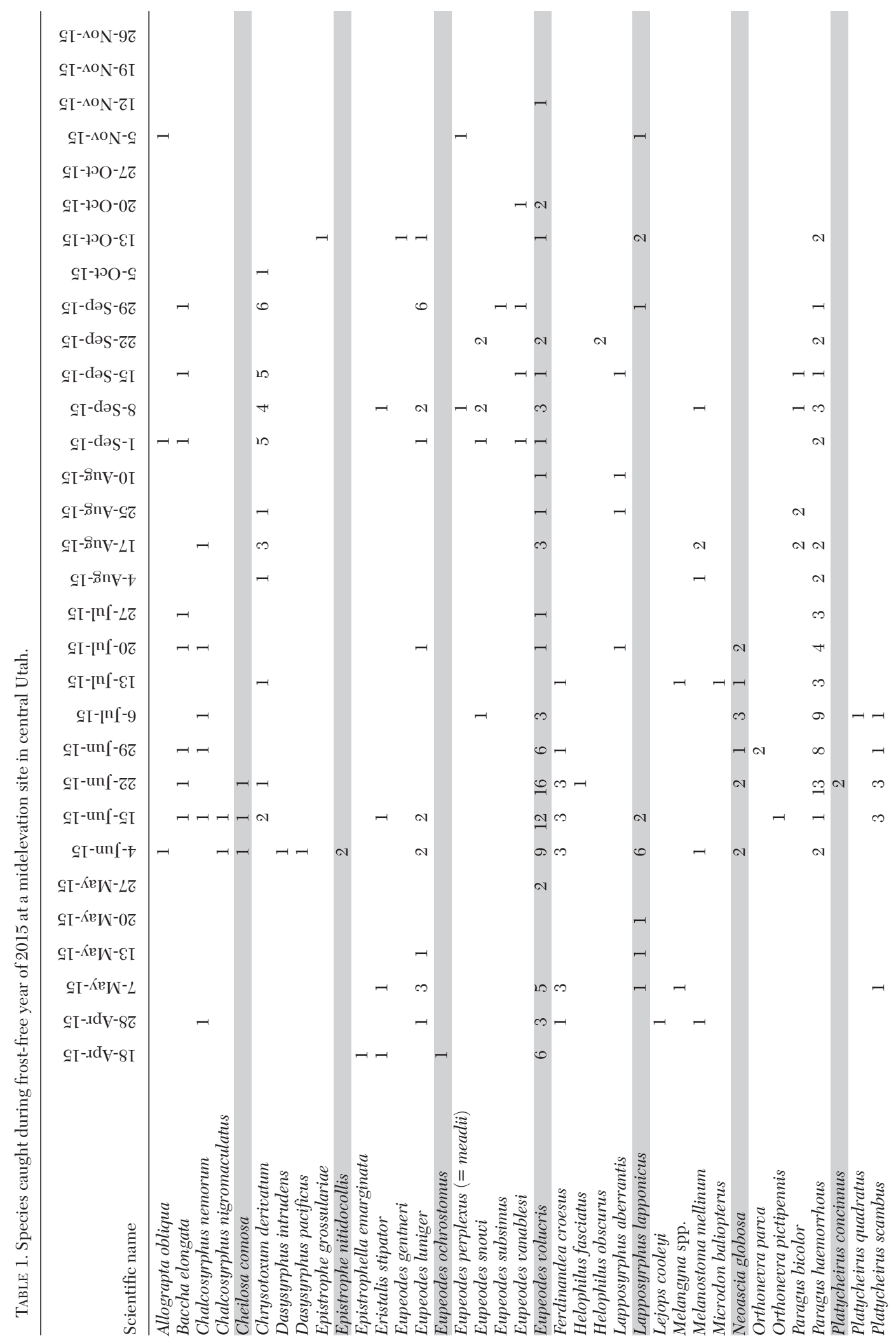




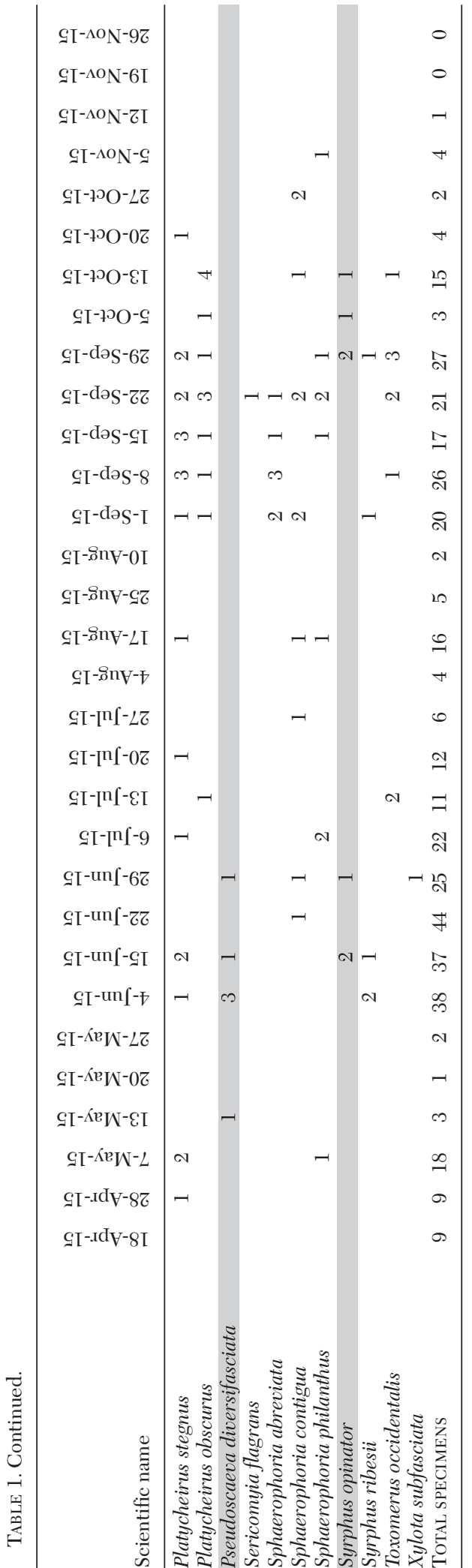

We used EstimateS 9.0 (Colwell 2013) to calculate richness indicators that fit a samplebased analysis of collected specimens. There are many statistically proven indicators for biodiversity. We chose our indicators based on several factors. We chose Chao 1 as an indicator because it preserves spatial structure of the data, which may reflect aggregation and segregation within and between species, whereas Chao 2 assumes complete random mixing among individuals of all species (Gotelli and Colwell 2011). For this reason, Chao 1 (sample-based rarefaction) is more realistic for independent sampling units and was thus useful in this study, which utilizes 3 different traps and environments. The coefficient of variation $(\mathrm{CV})$ for incidence distribution was 0.503 . Because $\mathrm{CV}$ was greater than 0.5 , we computed Chao 1 using the classic option as opposed to the bias-corrected option. In summary, the indicators we used were the abundance coverage-based estimator of species richness ACE (mean among runs) (Chao et al. 2000), the Chao 1 richness estimator (mean among runs), and the Michaelis-Menten richness estimator as computed by equation 5 in Colwell et al. (2004).

Along with biodiversity indicators, we used EstimateS 9.0 (Colwell 2013) to calculate a rarefaction curve. We calculated our rarefaction values as in Coleman (1981) and Coleman et al. (1982). In sample-based rarefaction and extrapolation, EstimateS uses the Bernoulli product model (Colwell et al. 2012). A rarefaction curve gives additional statistical information regarding the sampling, but the sampling needs to meet certain criteria in order to provide accurate information. Assumptions for rarefaction include sufficient sampling, comparable sampling methods, taxonomic similarity, closed communities of discrete individuals, random placement, and independent random sampling (Gotelli and Colwell 2011). Our study exceeded the recommended 20 individuals and 20 samples suggested by Gotelli and Colwell (2011) to have sufficient sampling to allow rarefaction. Our sampling methods were consistent, as our traps did not vary in their construction, setup, or dimensions across different trap locations. Our specimens were of the same taxonomic group. All specimens used in this study were identified to the same taxonomic group of Syrphidae by the same identifier. Syrphidae in this study were considered 


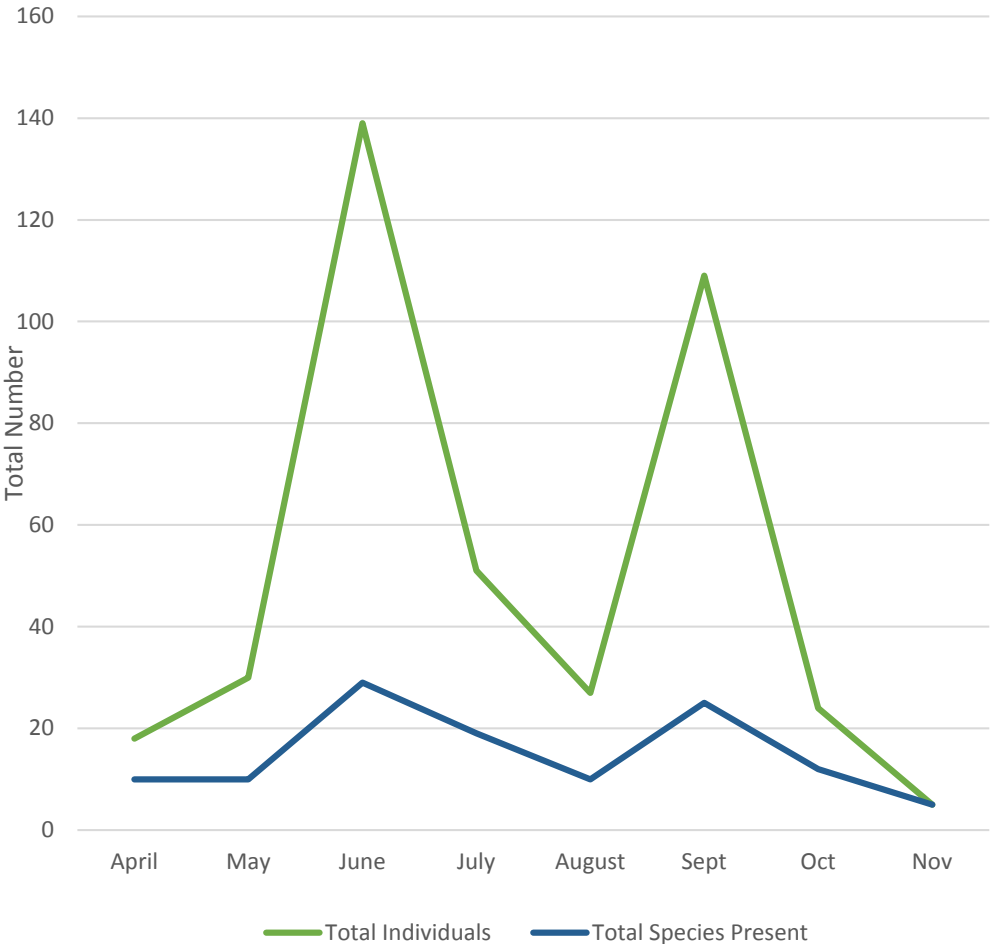

Fig. 2. Total number of individuals and total number of species of Syrphidae caught during each month at the study site in central Utah.

consistent, and their presence in multiple samples was detectable. Our use of samplebased rarefaction from several trap locations overcame small-scale sampling bias. Sampling methods were random and approximately independent because collection was via consistently run Malaise traps over the flight season of Syrphidae in Utah. Collection likely did not affect the large assemblage of the population, and thus, collections approximated results using random replacement.

We determined temperature averages from recorded data that was measured at the mouth of the canyon during the year of the study $\left(40.0797^{\circ} \mathrm{N}, 111.604^{\circ} \mathrm{W}\right.$; U.S. Climate Data 2016). This location is 15 miles down-canyon from our study site, and though the numbers may not reflect exact temperatures, we believe they are representative of temperature trends for our site.

\section{RESUlTS}

We identified a total of 404 hover fly specimens to the species level (Table 1). This yielded 27 genera and 48 species collected during the trapping period. Overall abundance curves (Fig. 2) are dominated by the genera Paragus and Eupeodes, which were the most abundant taxa (Table 1, Fig. 3). These 2 genera accounted for $44 \%$ of the total number of syrphids and $21 \%$ of the species collected. The driest months of the year on average (July and August) showed a lower total abundance than the earlier and subsequent months. Thus, we see bimodal distribution for abundances. Despite the lower abundances of July and August, these months exhibited diversity values close to those of wetter months (Table 2).

During the study, we noticed large variation in yield from the different trap locations. Trap 1 (wooded area, over first-order stream, small canyon) produced more consistent yields than the other 2 traps. Trap 2 (second-order stream, larger canyon, little to no shade) produced yields consistent with trap 3 (base of first-order stream waterfall, little shade, hygropetric environments); both traps had large spikes in yield during the spring and late fall. The abundant and diverse taxon Eupeodes 


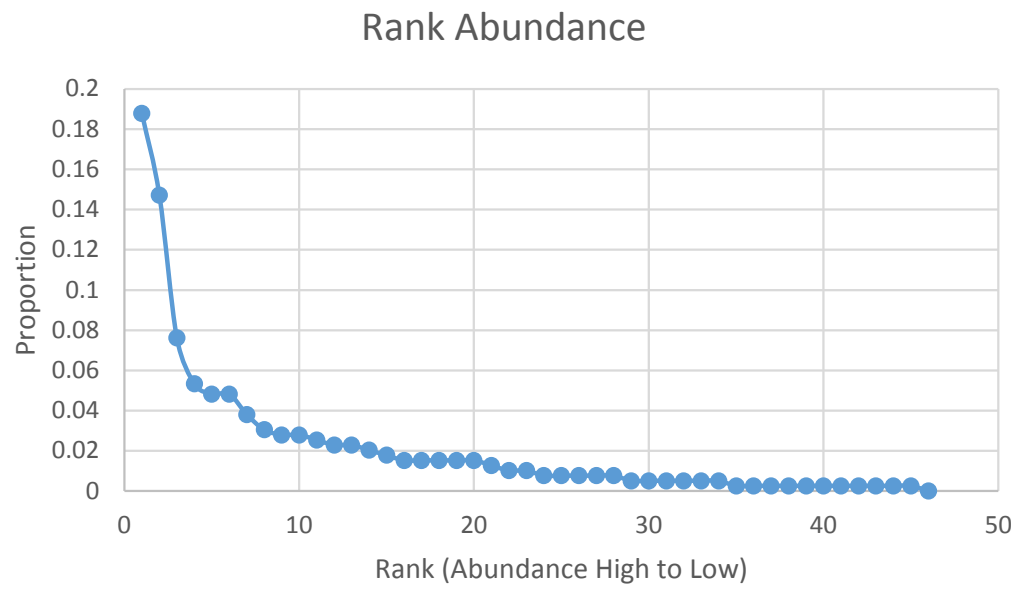

Fig. 3. Rank abundance curve that shows the distribution and rarity of syrphid taxa caught at the study site in central Utah. The most abundant species was Eupeodes volucris, followed by Paragus haemorrhous, Chrysotoxum derivatum, Platycheirus stegnus, and Eupeodes luniger, respectively.

TABLE 2. Diversity, richness, and abundance of hover flies (Diptera: Syrphidae) at a midelevation central Utah study site summarized by month, along with monthly averages of temperature and precipitation from historic data retrieved from U.S. Climate Data (2016). Diversity values are calculated according to the Shannon's diversity index formula: $H_{j}=$ $-\sum p_{i j} \log _{\mathrm{e}}\left(p_{i j}\right)$. Total individuals is the total number of specimens caught during the month. Total species present is the total number of distinct species caught during the month at the study site.

\begin{tabular}{lcccccccc}
\hline & Apr & May & Jun & Jul & Aug & Sep & Oct & Nov \\
\hline Diversity (Shannon's index) & 1.79 & 1.83 & 2.58 & 2.33 & 2.12 & 2.84 & 2.32 & 1.61 \\
Total individuals & 18 & 30 & 139 & 51 & 27 & 109 & 24 & 5 \\
Total species present & 10 & 10 & 29 & 19 & 10 & 25 & 12 & 5 \\
Precipitation $(\mathrm{cm})$ & 5.9 & 8.7 & 0.3 & 1.5 & 4.0 & 0.91 & 1.4 & 3.6 \\
Average high $\left({ }^{\circ} \mathrm{C}\right)$ & 19.4 & 21.0 & 33.2 & 32 & 32.4 & 29.1 & 21.6 & 9.2 \\
Average low $\left({ }^{\circ} \mathrm{C}\right)$ & 3.1 & 8.2 & 14.7 & 15.2 & 15.6 & 12.4 & 8.3 & -1.4 \\
\hline
\end{tabular}

(Metasyrphus) was collected mostly from trap 2, whereas the other subgenus, Eupeodes (Eupeodes), was collected more in the small canyon at traps 1 and 3 . The abundant taxon Paragus was caught mostly at trap 1 .

The most abundant genera collected during the study belong to the tribes Syrphini, Paragini, and Melanostomini. Syrphini (47\%) were by far the most abundant. Within this tribe, genera such as Eupeodes show diversity and abundance of many species with overlapping flight seasons. It is surprising that this genus with aphidophagous behavior in its immature stages is so diverse despite requiring specific larval resources (Sedman 1952, Henderson 1982).

The 2 subgenera of the genus Eupeodes overlap in their flight seasons, yet peak abundances occur in different seasons. Eupeodes (Eupeodes) peaks in the late spring, whereas Eupeodes (Metasyrphus) peaks in the fall (Fig. 4). Though they exhibit different peak abundance patterns, both taxa exhibit small peaks during the larger peaks of the other species.

The second most abundant species at the study site, Paragus haemorrhous, rose sharply in abundance at the end of the month of June, then slowly declined throughout the rest of the flight season, with only a slight increase during the late fall (Fig. 5). During the decline and lower abundances of $P$. haemorrhous, another member of its genus, $P$. bicolor, appeared in low abundances.

Sphaerophoria spp. exhibited high abundances in the spring, but decreased abruptly during the month of July (Fig. 6). Lower abundances remained until the end of fall. Platycheirus spp. and Chrysotoxum sp. exhibited higher abundances in the fall (Figs. 7, 8).

Records from the MLBM indicate that another 28 species have been collected in close 


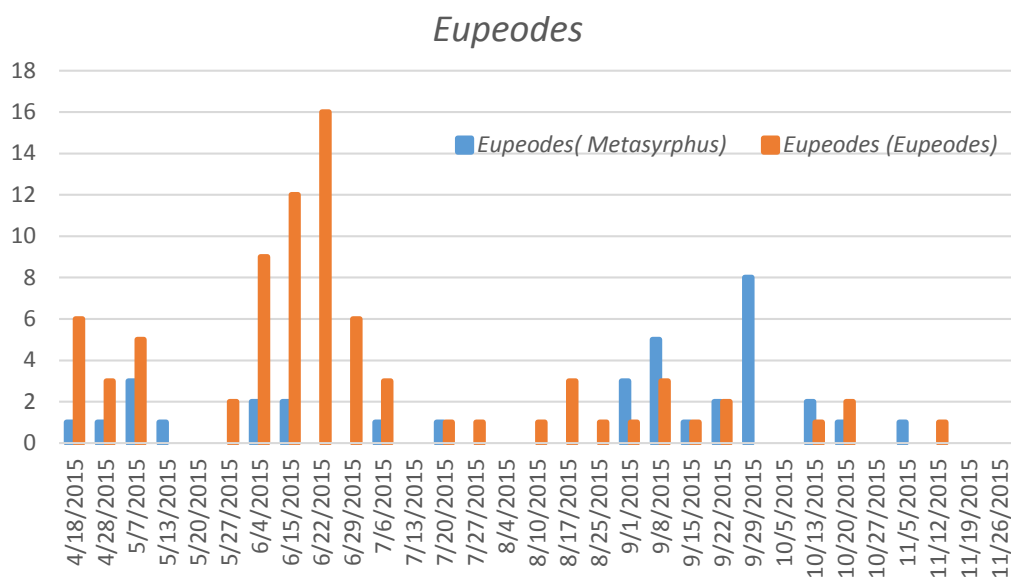

Fig. 4. Number of specimens belonging to Eupeodes (Metasyrphus) and Eupeodes (Eupeodes) caught over the frost-free year at the study site in Spanish Fork Canyon, Utah.

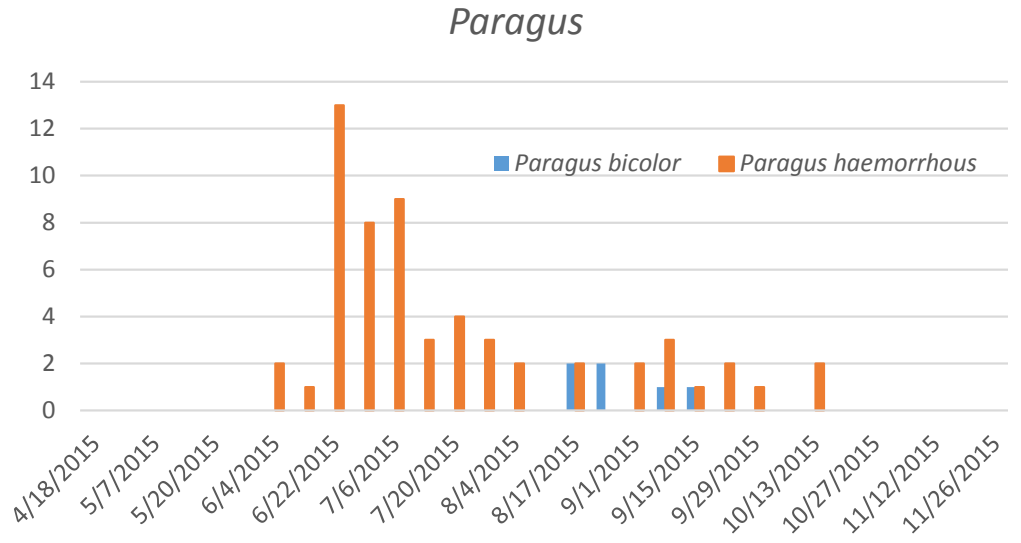

Fig. 5. Total number of specimens belonging to Paragus haemorrhous and Paragus bicolor caught over the frost-free year at the study site in Spanish Fork Canyon, Utah.

proximity to the study area in years before 2000 (Table 3). From the 28 missing species, 11 genera were not observed at the sample site.

Cole rarefaction calculations reflect a diversity level close to what was observed in our catch, while richness estimators reflect a gap of 10-12 missing species. The Michaelis-Menten richness estimator indicates that with 30 samples, the community should contain 58 species, and Cole rarefaction indicates that 50 species should be present with 30 samples (Fig. 9).

\section{Discussion}

This study provides information about the species composition and flight season of the family Syrphidae from a single locality. Thorough sampling was done during the flight season of one year. We identified and summarized all records of distribution and abundance for these syrphids (Table 1). We now have a much better understanding of the diversity of this local system.

We determined that the basic biology (flight seasons, biodiversity, and general abundances) of the hover fly community in this system can be addressed with thorough sampling over a single full flight season. We would prefer to have more years of data, but that is not possible at this time.

The drop in total abundance and species richness during July and August reflects a 


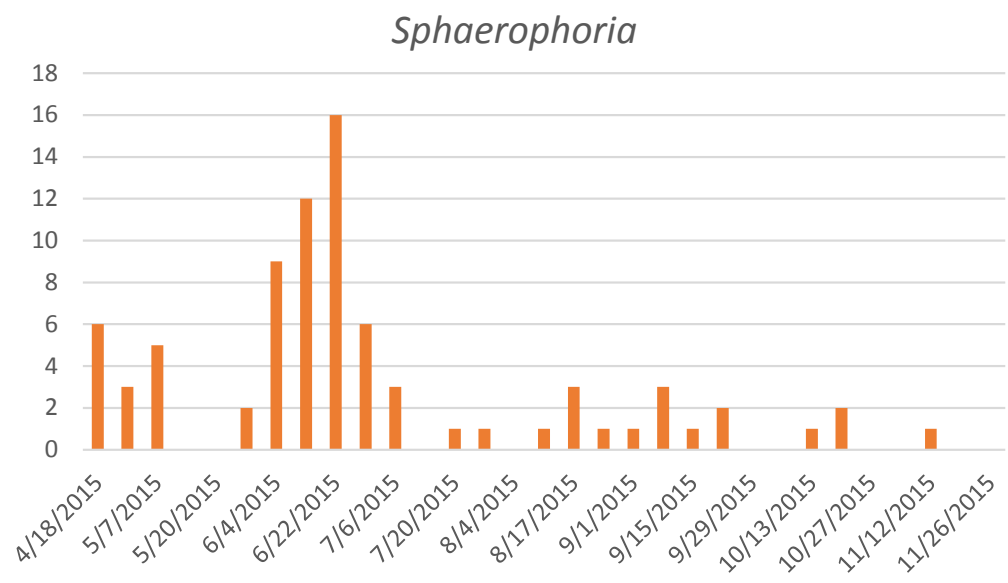

Fig. 6. Total number of specimens belonging to 3 species on site of the genus Sphaerophoria caught over frost-free year at the study site in Spanish Fork Canyon, Utah.

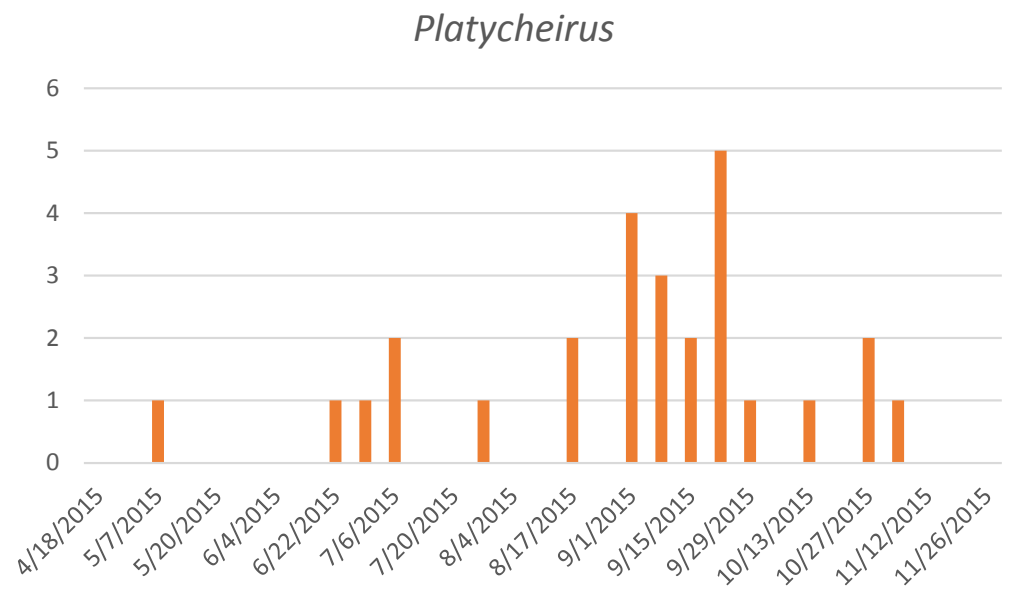

Fig. 7. Total number of specimens belonging to the 5 species of the genus Platycheirus caught over the frost-free year at the study site in Spanish Fork Canyon, Utah.

possible response of Syrphidae to drier conditions during those months (Fig. 2). Although the response of hover flies to drier and hotter months is unclear in the literature, their abundance patterns seem to be affected more by high temperatures when historic temperatures are examined. On average, the hottest months during the past 5 years were July and August (U.S. Climate Data 2016), but according to available temperature data, June was the hottest month during the study year. Despite having the highest average monthly temperature, June exhibited the highest number of total individuals and species (Table 2, Fig. 2). Once the historically hotter months began, we saw a dramatic drop in the abundance of many taxa. It appears that high temperatures may have a strong effect on hover fly abundance and that low precipitation levels don't present large immediate effects (Table 2). The factors that shape the abundance curves and life history strategies of hover flies are difficult to determine from our data. We speculate that hover flies are likely adapted to the more productive vegetation of the spring and fall, which was still present in the hotter month of June. Further studies are needed to determine the accompanying change in plant resources during the drop in hover fly abundance to determine whether the effect of heat on 


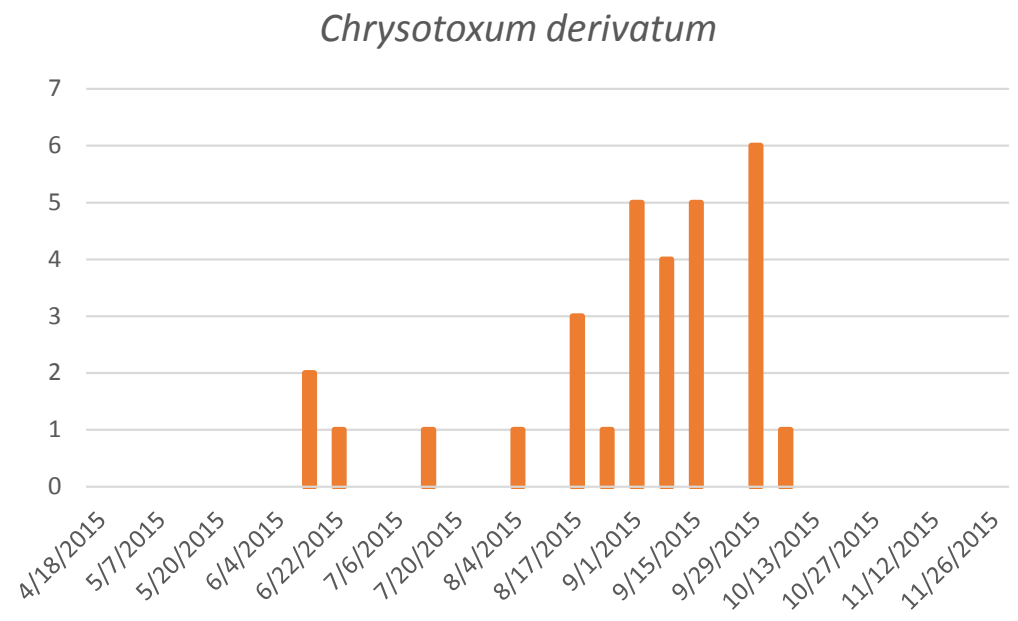

Fig. 8. Total number of Chrysotoxum derivatum specimens caught over the frost-free year at the study site in Spanish Fork Canyon, Utah.

TABLE 3. Historic species of Syrphidae deposited in the Monte L. Bean Life Science Museum that were collected within $40 \mathrm{~km}$ and $500 \mathrm{~m}$ elevation of the study site in Spanish Fork Canyon, Utah, that were missing from our study.

\begin{tabular}{ll}
\hline Species & Author \\
\hline Blera nigra & (Williston, 1887) \\
Brachyopa flavescens & Shannon, 1915 \\
Brachyopa ferruginea & (Fallen, 1817) \\
Brachypalpus femorata & (Williston, 1882) \\
Brachypalpus oarus & (Walker, 1849) \\
Ceriana tridens & (Loew, 1872) \\
Cheilosia pikei & (Shannon, 1922) \\
Copestylum marginatum & Say, 1892 \\
Copestylum satur & (Osten Sacken, 1877) \\
Didea fuscipes & Loew, 1863 \\
Eristalis anthophorina & (Fallen, 1817) \\
Eristalis brousii & Williston, 1882 \\
Eristalis flavipes & Walker, 1849 \\
Eristalis hirta & Loew, 1866 \\
Eristalis tenax & (Linnaeus, 1758) \\
Helophilus obscurus & Loew, 1863 \\
Lejops curvipes & (Wiedemann, 1830) \\
Lejops polygrammus & (Loew, 1872) \\
Microdon baliopterus & (Loew, 1872) \\
Microdon xanthopilis & Towsend, 1895 \\
Neoascia sphaerophoria & Curran, 1925 \\
Scaeva pyrastri & (Linnaeus, 1758) \\
Sericomyia militaris & Walker, 1849 \\
Spilomyia liturata & Williston, 1887 \\
Syritta pipiens & Linnaeus, 1758 \\
Toxomerus marginatus & (Say, 1823) \\
Tropidia quadrata & (Say, 1824) \\
Volucella spp. & Geoffroy, 1762 \\
\hline &
\end{tabular}

hover fly abundance is physiological or whether it is indirect through its effect on vegetation.

Although we cannot determine an unequivocal relationship between hover fly abundance and hotter months, we do see that many taxa seem less able to cope with hotter and drier months within our study (Fig. 2). Paragus is an exception (Fig. 5). Sphaerophoria and Eupeodes accounted for the most individuals at our study site, and were found throughout the flight season. They were present in moderately high numbers in the early spring and persisted in small numbers until late November. Sphaerophoria and Eupeodes show resilience to cold temperatures, with high abundances in almost freezing conditions, yet exhibited a sharp decrease in total abundance during the hotter months (on average) of July and August (Figs. 4-6). This result fits data from other studies showing a sharp drop in fitness at higher temperatures (Deutsch et al. 2008). If the indicated trend of intolerance to higher temperatures (on average) is significant, then there is potential concern that climate change would result in shifts of flight season toward cooler months for these sensitive taxa and possibly reduce total abundance as populations respond to higher temperatures year-round.

Analyses of the species richness indicator Chao 1, the coverage indicator ACE, and the Michaelis-Menten richness estimator (asymptote of species accumulation curve) reveal that several more species likely exist at the study site that were not collected (Fig. 9). Both rarefaction and richness estimators indicate more species, but the missing historic taxa support the diversity indicators over the rarefaction 


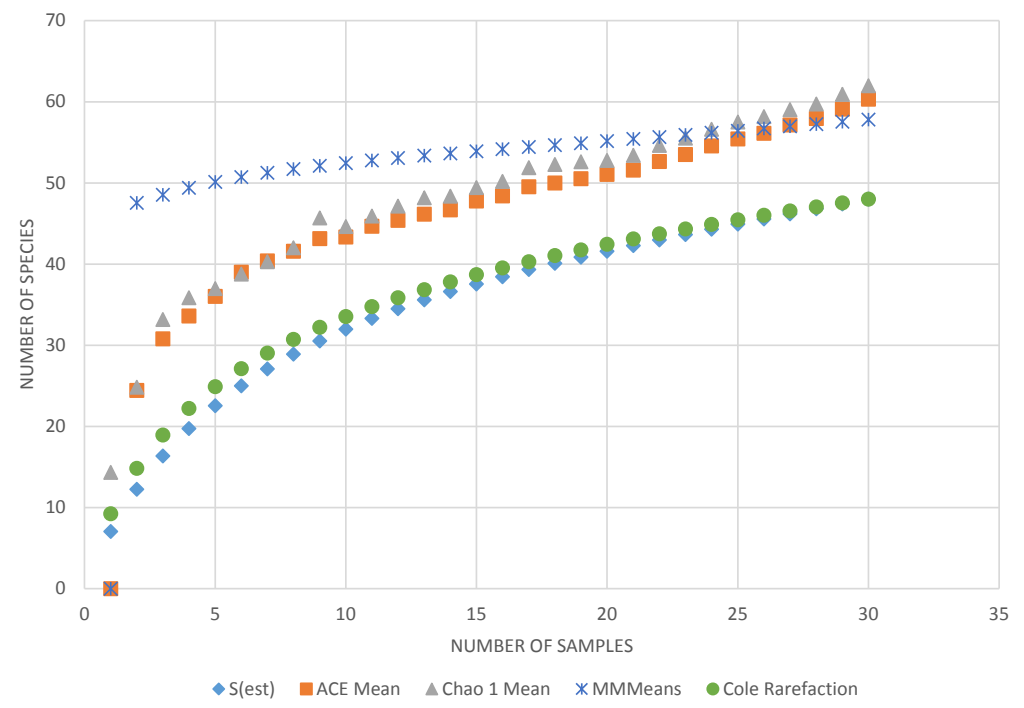

Fig. 9. Comparison of species accumulation curves using rarefaction and richness estimators. S(est) = the expected number of species of Syrphidae from the study site in Spanish Fork Canyon, Utah, in $t$ pooled samples, given the reference sample (analytical). ACE mean = ACE abundance coverage-based estimator of species richness (mean among runs). Chao 1 mean = Chao 1 richness estimator (mean among runs), MMMeans = Michaelis-Menten richness estimator; both are estimators computed once for the analytical rarefaction curve. Cole rarefaction $=$ Coleman rarefaction (number of species expected in $t$ pooled samples, assuming that individuals are distributed at random among samples).

estimate in the scope of how many more species are in the study area or its environs (Table 3). This may indicate that richness estimators are more representative of actual population composition than rarefaction. Our study seems to suggest that the richness indicators are more accurate than rarefaction as we compared our year's catch with the historic taxa. Rank abundance curves show a relatively standard pattern, indicating that the remaining taxa that we didn't collect during the study are likely rare species (Fig. 3)

Successful future studies would likely be able to approach a full sample of the population with more traps in more diverse locations. We estimate that with 2 traps in each type of terrain, yields would closely approximate richness estimators. Each designated representative zone could be sampled with 2 traps in diverse locations within the same terrain type. With emphasis on size and extent of collection, rarefaction and richness estimators give accurate representations of the system (Chao and Jost 2012).

During the study we identified many taxa of the same tribe, genus, and subgenus level that overlap in their flight seasons. This is especially apparent for Eupeodes and Platycheirus.
We do not know how the several species belonging to Eupeodes interact on a limited resource (such as aphids or pollen) on the genus, subgenus, and species level. Taxa belonging to the tribe Syrphini were very abundant and are likely to exhibit an interesting interaction as they conceivably compete for pollen and larval resources. Future research could focus on niche breadth of these taxa. It is possible that diversity of aphids is a significant driver of speciation and diversity within the system at our test site, but due to the diverse nature of aphids and their complex life cycle (Knowlton 1924, 1983), a specific study would be needed to determine relationships. It would be interesting to determine whether larval feeding habits of aphidophagous Syrphidae are conspecific or whether different Syrphidae species feed on different life stages of aphids.

With regards to Eupeodes, it is surprising to see this genus so abundant, diverse, and overlapping in species flight seasons because of its aphidophagous behavior in its immature stages (Sedman 1952, Henderson 1982). There is likely an interesting interaction on the species level as individuals compete for proper egg-laying habitat and pollen as adults and aphid prey as immatures. We caught 7 species 
of Eupeodes (Metasyrphus) during the study, along with 1 species of the closely related subgenus Eupeodes (Eupeodes). Both subgenera overlap in flight season, and at the species level we see many overlaps. Within the subgenus Metasyrphus, the species ochrostomus, luniger, and snowi overlap in the early season. In the late season, luniger, snowi, perplexus, vanblesi, gentneri, and subsimus occur (all members of Metasyrphus). This overlap in the late season involves 8 species of Eupeodes within a period of 10 weeks (Table 1 ). We do see a slight difference as the Metasyrphus subgenus peaks more in the fall, whereas the Eupeodes subgenus peaks in the late spring. Rising summer temperatures may have played a role in the separation of these 2 subgenera. We see a similar pattern on the subgenus level with the Paragus taxa.

We conducted this study to understand the composition of hover fly species and their changes in abundance throughout the flight year. This study has revealed an incredible diversity and variation within the Syrphidae. Sampling from several sites has allowed us to see a large variation in flight seasons between species. With use of richness indicators and a rarefaction curve, we were able to more fully determine the richness of the system. Many interesting questions and relationships were exposed. We now understand the main composition of Syrphidae in respect to this system, and we hope that this study aids future research in determining drivers and maintainers of biodiversity, richness, and flight seasons of hover flies in Utah and throughout the world.

\section{Literature Cited}

Biesmejer, J.C., S.P.M. Roberts, M. Reemer, R. Ohlemüller, M. Edwards, T. Peeters, and J. SetTELE. 2006. Parallel declines in pollinators and insect-pollinated plants in Britain and the Netherlands. Science 313:351-354.

ChaO, A., W.H. Hwang, Y.C. Chen, and C.Y. Kuo. 2000 Estimating the number of shared species in two communities. Statistica Sinica 10:227-246.

ChaO, A., AND L. Jost. 2012. Coverage-based rarefaction and extrapolation: standardizing samples by completeness rather than size. Ecology 93:2533-2547.

Coleman, B.D. 1981. On random placement and speciesarea relations. Math Bioscience 54:191-215.

Coleman, B.D., M.A. Mares, M.R. Willig, and Y.H HsieH. 1982. Randomness, area, and species richness. Ecology 63:1121-1133.

Colwell, R.K. 2013. EstimateS: statistical estimation of species richness and shared species from samples.
Version 9. User's guide and application. http://purl .oclc.org/estimates

Colwell, R.K., A. ChaO, N.J. Gotelli, S.Y. Lin, C.X. MaO, R.L. ChaZdon, AND J.T. Longino. 2012. Models and estimators linking individual-based and samplebased rarefaction, extrapolation and comparison of assemblages. Journal of Plant Ecology 5:3-21.

Colwell, R.K., C.X. MaO, AND J. Chang. 2004. Interpolating, extrapolating, and comparing incidence-based species accumulation curves. Ecology 85:2717-2727.

Deutsch, C.A., J.J. Tewksbury, R.B. Huey, K.S. Sheldon, C.K. Ghalambor, D.C. HaAk, and P.R. Martin. 2008. Impacts of climate warming on terrestrial ectotherms across latitude. Proceedings of the National Academy of Sciences 105:6668-6672.

Division of Water Quality. 2014. Utah's Year 2002 303(d) list of waters submitted in fulfillment of Section 303(d) of the Clean Water Act, Department of Environmental Quality, Salt Lake City, UT.

[EPA] Environmental Protection Agency. 2006. Total maximum daily load (TMDL) water quality analysis of Soldier Creek Watershed, Utah, EPA, Utah. http:// www.deq.utah.gov/ProgramsServices/programs/water/ watersheds/docs/2007/08Aug/Soldier_Creek_TMDL .pdf

Gotelli, N.J., And R.K. Colwell. 2011. Estimating species richness. Frontiers in Measuring Biodiversity $12: 39-54$

HasletT, J.R. 1989. Adult feeding by holometabolous insects: pollen and nectar as complementary nutrient sources for Rhingia campestris (Diptera: Syrphidae). Oecologia 81:361-363.

Henderson, D.H. 1982. Fine structure and neurophysiology of a gustatory sensillum on the ovipositors of Metasyrphus venablesi and Eupeodes volucris (Diptera: Syrphidae). Canadian Journal of Zoology 60: 3187-3195.

Holloway, B.A. 1976. Pollen feeding in hover flies (Diptera: Syrphidae). New Zealand Journal of Zoology 3:339-350.

Inouye, D.W., B.M.H. Larson, A. Ssymank, and P.G. KEVAN. 2015. Flies and flowers III: ecology of foraging and pollination. Journal of Pollination Ecology 16:115-133.

KEARns, C.A. 1990. The role of fly pollination in montane habitats. Doctoral dissertation, University of Maryland, College Park, MD.

KeVAN, P.G. 1972. Insect pollination of high arctic flowers. Journal of Ecology 60:831-847.

KevaN, P.G. 1999. Pollinators as bioindicators of the state of the environment: species, activity and diversity. Agriculture, Ecosystems and Environment 74:373-393.

Kevan, P.G., AND H.G. BAKER. 1983. Insects as flower visitors and pollinators. Annual Review of Entomology 28:407-453.

Knowlton, G. 1924. A contribution to our knowledge of the Aphididae of Utah. Master's thesis, Utah State University, Logan, UT. http://digitalcommons.usu .edu/etd/1581

Knowlton, G.F. 1983. Aphids of Utah. Utah State Agricultural Experiment Station Research Bulletin 509: December.

Larson, B.M.H., P.G. Kevan, and D.W. Inouye. 2001. Flies and flowers: taxonomic diversity of anthophiles and pollinators. Canadian Entomologist 133:439-465.

Miranda, G.F.G., A.D. Young, M.M. Locke, S.A. MarShall, J.H. Skevington, And F.C. Thompson. 2013. 
Key to the genera of Nearctic Syrphidae. Canadian Journal of Arthropod Identification 23:1-351.

Schoeneberger, M.M. 1992. Enhancing biodiversity with and within agroforestry plantings. USDA Forest Service/UNL Faculty Publications. http://digital commons.unl.edu/usdafsfacpub/28.

Sedman, Y.S. 1952. The Syrphidae of Utah. Master's thesis, University of Utah, Salt Lake City, UT.

SommagGio, D. 1999. Syrphidae: can they be used as environmental bioindicators? Agriculture, Ecosystems and Environment 74:343-356.

Speight, M.C.D. 1986. Criteria for the selection of insects to be used as bioindicators in nature conservation research. Pages 485-488 in Procedures of the 3rd European Congress of Entomology, Amsterdam.

Speight, M.C.D., and E. Castella. 1993. Bugs in the system: relationships between distribution data, habitat and site evaluation in development of an environmental assessment procedure based on invertebrates. Pages 1-9 in I. Valovivta, P.T. Harding, and D. Kime, editors, Proceedings of the 9th International Survey, Helsinki, 3-4 September 1993. WWF Finland.
SsYmanK, A. 2003. Habitatnutzung blütenbesuchender Schwebfliegen (Diptera, Syrphidae) in Wald-Offenland-Vegetationsmosaiken. Berichte der ReinholdTüxen-Gesellschaft 15:215-228.

Ssymank, A., C.A. Kearns, T. Pape, and F.C. Thompson. 2008. Pollinating flies (Diptera): a major contribution to plant diversity and agricultural production. Biodiversity 9:86-89.

Stanley, D.A., D. Gunning, and J.C. Stout. 2013. Pollinators and pollination of oilseed rape crops (Brassica napus L.) in Ireland: ecological and economic incentives for pollinator conservation. Journal of Insect Conservation 17:1181-1189.

Thompson, F.C., AND J.R. Vockeroth. 1989. 51. Family Syrphidae. Bishop Museum Special Publications 86:437-458.

U.S. Climate Data. 2016. Temperature. [Accessed 1 May 2016]. http://www.usclimatedata.com/

Received 9 December 2016 Accepted 5 August 2017 Published online 12 January 2018 